\title{
Environmental Restoration and Waste Management Department Independent Safety Review Committee Program Management Plan
}

Published October 1992

\author{
Idaho National Engineering Laboratory \\ EG\&G Idaho, Inc. \\ Idaho Falls, Idaho 83415
}




\section{Environmental Restoration and Waste Management Department Independent Safety Review Committee Program Management Plan}

EGG-WMO-10456

Approved by:

RMshaw

R. M. Shaw

DOE-ID $\frac{10 / 19 / 92}{\text { Date }}$

$9-22-92$

Date

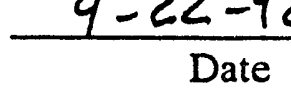

\section{J. L. Adually}

Environmental Restorat on and Waste Management (ER\&WM)

Department Manager

Reviewed by:

S. G. Stiger
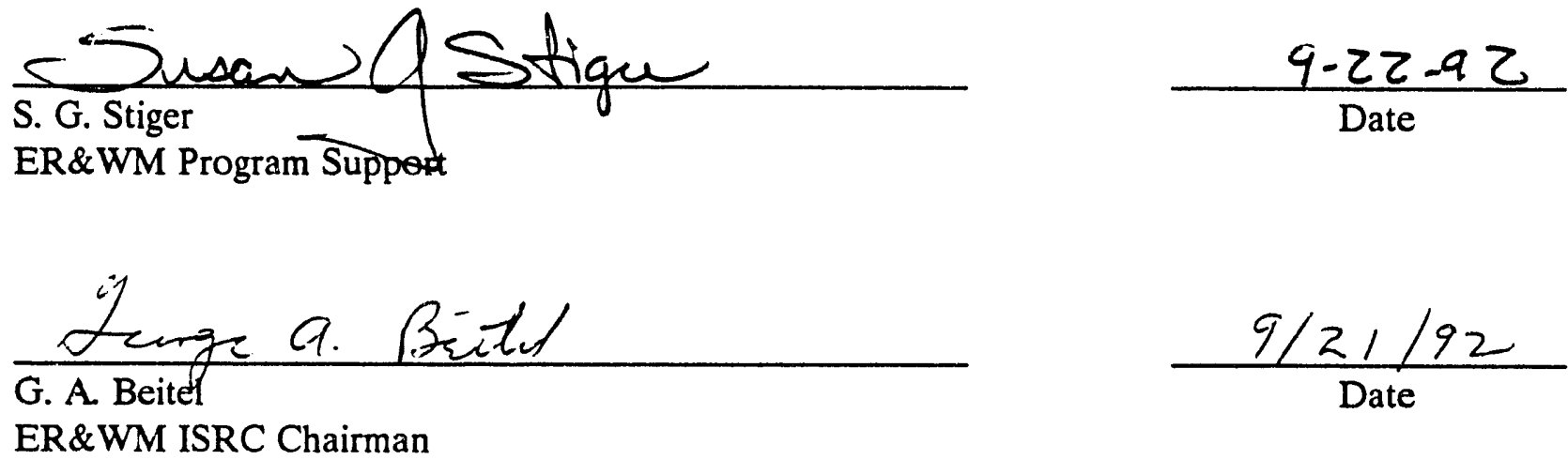

Prepared by:
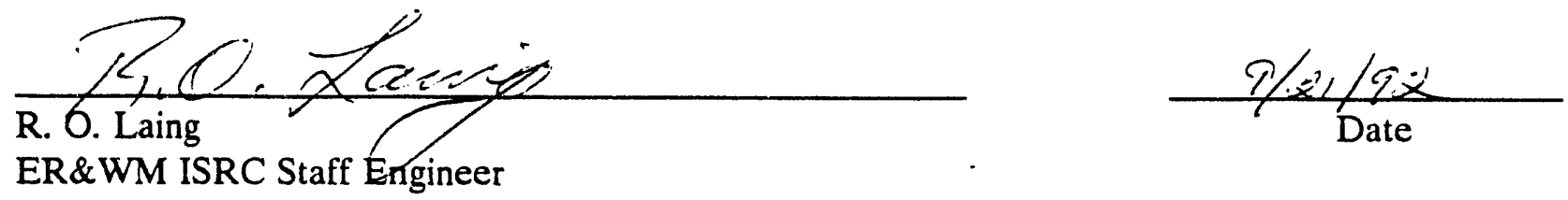


\section{FOREWORD}

The Program Management Plan for the Independent Safety Review Committee (ISRC) of EG\&G Idaho, Inc.'s Environmental Restoration and Waste Management Department (ER\&WMD) sets forth the plans, organizations, and systems for conducting independent safety reviews within the ER\&WMD. This PMP is consistent with U.S. Department of Energy (DOE) Order 5480.5 and applicable subordinate documents; and is kept current by annual review and appropriate updating.

This document defines the scope of the ISRC and addresses the required aspects of program control. Although the ISRC is not a "program" in the classical sense of a product-oriented research and development or construction project, the requirements for a Project Management Plan, as described in DOE Order 4700.1, Project Management System, were incorporated into this document and all sections suggested in DOE Order 4700.1, have been addressed where applicable. This plan describes the activities, funding, governing requirements, organizational responsibilities, milestones, and interfaces critical to the functioning of the ISRC. 


\section{CONTENTS}

FOREWORD $\ldots \ldots \ldots \ldots \ldots \ldots \ldots \ldots \ldots \ldots \ldots \ldots \ldots \ldots \ldots \ldots$

ACRONYMS $\ldots \ldots \ldots \ldots \ldots \ldots \ldots \ldots \ldots \ldots \ldots \ldots \ldots \ldots \ldots \ldots \ldots \ldots$

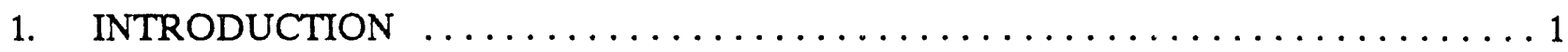

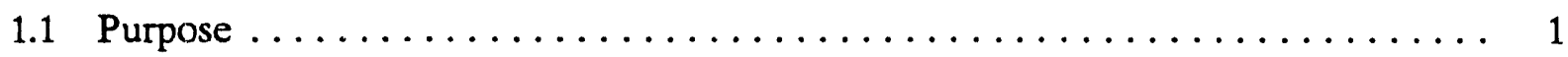

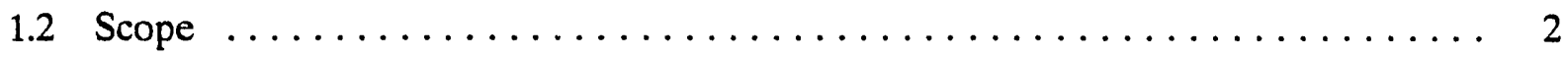

2. MISSION, GOALS, AND OBJECTIVES $\ldots \ldots \ldots \ldots \ldots \ldots \ldots \ldots \ldots \ldots$

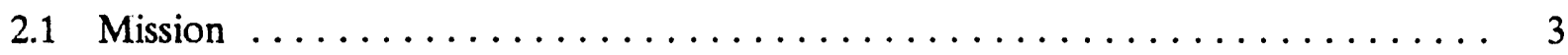

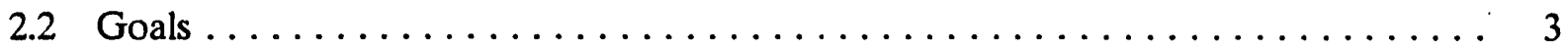

2.3 Technical Baseline Objectives $\ldots \ldots \ldots \ldots \ldots \ldots \ldots \ldots \ldots \ldots \ldots \ldots \ldots$

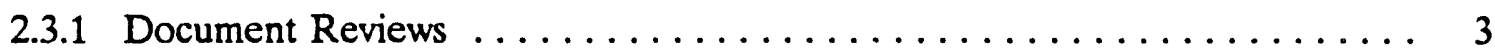

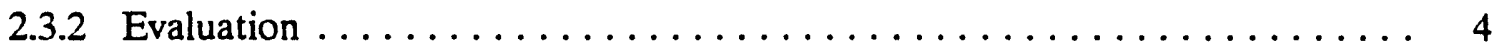

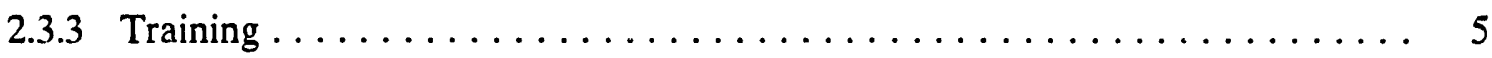

3. Organization and Responsibilities $\ldots \ldots \ldots \ldots \ldots \ldots \ldots \ldots \ldots \ldots \ldots \ldots \ldots \ldots \ldots \ldots \ldots$

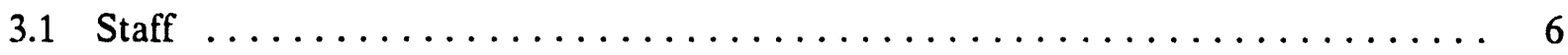

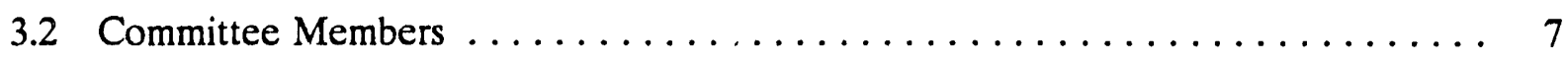

4. WORK PLAN $\ldots \ldots \ldots \ldots \ldots \ldots \ldots \ldots \ldots \ldots \ldots \ldots \ldots \ldots$

4.1 Program Management $\ldots \ldots \ldots \ldots \ldots \ldots \ldots \ldots \ldots \ldots \ldots \ldots \ldots$

4.1.1 Management Deliverables $\ldots \ldots \ldots \ldots \ldots \ldots \ldots \ldots \ldots \ldots \ldots \ldots$

4.2 Document Reviews $\ldots \ldots \ldots \ldots \ldots \ldots \ldots \ldots \ldots \ldots \ldots \ldots$

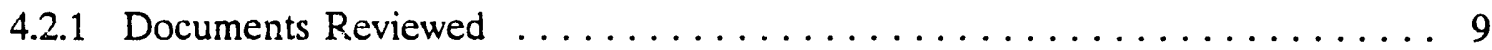

4.2 .2 Document Review Process . . . . . . . . . . . . . . . . . . . 10

4.2.3 Document Review Deliverables ...................... 10

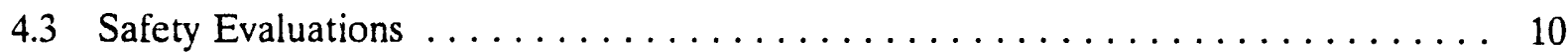

4.3.1 Safety Evaluation Deliverables $\ldots \ldots \ldots \ldots \ldots \ldots \ldots \ldots \ldots \ldots \ldots \ldots$ 
4.4 Training and Process Improvement $\ldots \ldots \ldots \ldots \ldots \ldots \ldots \ldots \ldots \ldots \ldots \ldots$

4.4.1 Training and Process Improvement Deliverables $\ldots \ldots \ldots \ldots \ldots \ldots$

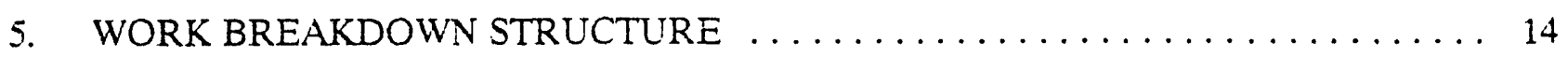

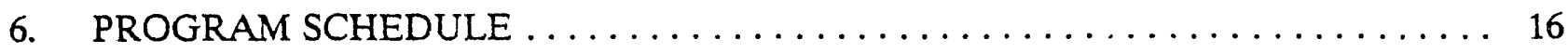

7. PERFORMANCE CRITERIA $\ldots \ldots \ldots \ldots \ldots \ldots \ldots \ldots \ldots \ldots \ldots \ldots \ldots$

7.1 Technical Performance Criteria $\ldots \ldots \ldots \ldots \ldots \ldots \ldots \ldots \ldots \ldots \ldots$

7.2 Schedule Performance Criteria . . . . . . . . . . . . . . . 17

7.3 Cost Performance Criteria $\ldots \ldots \ldots \ldots \ldots \ldots \ldots \ldots \ldots \ldots \ldots \ldots \ldots$

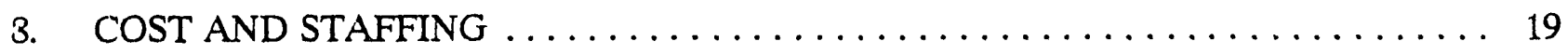

8.1 Annual Program Budget $\ldots \ldots \ldots \ldots \ldots \ldots \ldots \ldots \ldots \ldots \ldots \ldots \ldots \ldots$

8.2 Document Review Budget $\ldots \ldots \ldots \ldots \ldots \ldots \ldots \ldots \ldots \ldots \ldots \ldots \ldots$

8.3 Work Package $\ldots \ldots \ldots \ldots \ldots \ldots \ldots \ldots \ldots \ldots \ldots \ldots \ldots \ldots$

9. PROGRAM FUNCTIONAL SUPPORT REQUIREMENTS $\ldots \ldots \ldots \ldots \ldots \ldots$

9.1 Department of Energy, Idaho Field Office $\ldots \ldots \ldots \ldots \ldots \ldots \ldots \ldots \ldots$

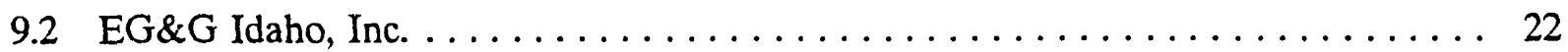

9.2.1 The Senior Management Review Group . . . . . . . . . . . . 22

9.2.2 The Environmental/OSHA Management Oversight Committee ........ 23

9.2.3 The Transport Plan Independent Review Committee .............. 23

9.2.4 EG\&G Idaho, Department Managers ................. 23

9.2.5 Safety and Operations Review Committee ................. 24

9.2.6 Combined Independent Safety Review Group . . . . . . . . . . . . 24

9.2.7 Independent Safety Review Committee ................. 24

10. PROJECT MANAGEMENT, MEASUREMENT, AND PLANNING AND

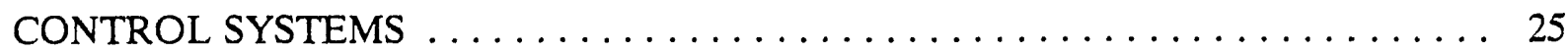

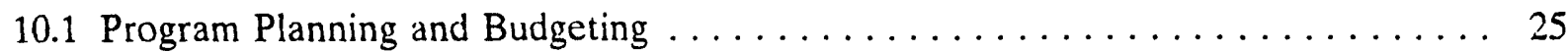

10.2 Performance Measurement and Control . . . . . . . . . . . 25

11. INFOFMATION AND REPORTING $\ldots \ldots \ldots \ldots \ldots \ldots \ldots \ldots \ldots \ldots \ldots$ 


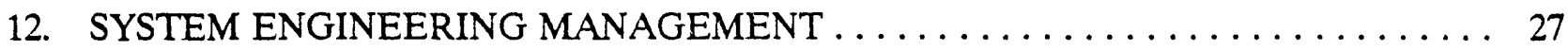

13. CONFIGURATION MANAGEMENT $\ldots \ldots \ldots \ldots \ldots \ldots \ldots \ldots \ldots \ldots$

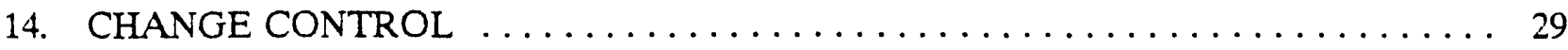

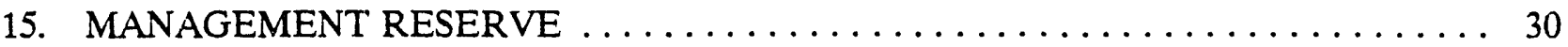

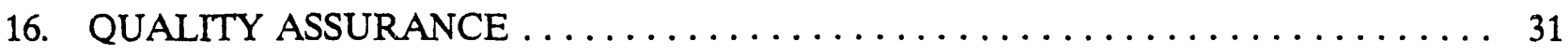

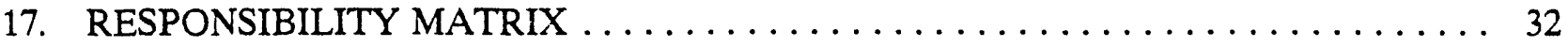

\section{FIGURES}

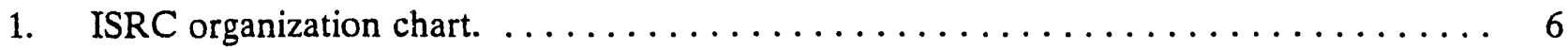

2. ISRC work breakdown structure. $\ldots \ldots \ldots \ldots \ldots \ldots \ldots \ldots \ldots \ldots \ldots \ldots$

3. EG\&G Idaho, Inc., independent review and appraisal system. $\ldots \ldots \ldots \ldots \ldots \ldots$

\section{TABLES}

1. Review standards and guidance documents. $\ldots \ldots \ldots \ldots \ldots \ldots \ldots \ldots \ldots \ldots \ldots$

2. Summary of deliverables. $\ldots \ldots \ldots \ldots \ldots \ldots \ldots \ldots \ldots \ldots \ldots \ldots \ldots \ldots \ldots \ldots$

3. The ISRC Quality Assurance Plan. $\ldots \ldots \ldots \ldots \ldots \ldots \ldots \ldots \ldots \ldots \ldots \ldots \ldots \ldots \ldots \ldots$ 


\section{ACRONYMS}

\begin{tabular}{ll} 
BUD & back-up documentation \\
CCB & Change Control Board \\
CISRG & Combined Independent Safety Review Group \\
DOE & Department of Energy \\
DOE-EM & Office of Environmental Restoration and Waste Management (DOE) \\
DOE-HQ & Department of Energy - Headquarters \\
DOE-ID & Department of Energy Idaho Field Office \\
EC & environmental compliance \\
EG\&G & EG\&G Idaho, Inc. \\
ERAD & Engineering Research and Application Department, EG\&G Idaho \\
ER\&WMD & Environmental Restoration and Waste Management Department, EG\&G Idaho \\
ES\&H & environment, safety, and health \\
ES\&Q & environment, safety, and quality \\
F\&M & Facilities and Maintenance Department, EG\&G Idaho \\
FCF & industrial safety \\
FSAR & facility change form \\
FTE & Final Safety Analysis Report \\
FY & full-time equivalent \\
HCD & health and safety plan \\
H\&SP & industrial hygiene \\
IH & Idaho National Engineering Laboratory \\
\hline
\end{tabular}


ISRC

LMIR

LOE

MCS

OR

PMP

PRPD

PSAR

QA

QA/QC

$\mathrm{QC}$

QAP

RS

SAR

SARP

SER

SMRG

SORC

TPIRC

TSR

USQ

USQD

WBS
Independent Safety Review Committee

line management independent review

level of effort

management control system

Occurrence Report

Program Management Plan

Power Reactor Programs Department, EG\&G Idaho

Preliminary Safety Analysis Report

quality assurance

quality assurance/quality control

quality control

Quality Assurance Plan

radiological safety

Safety Analysis Report

Safety Analysis Report for Packaging

Safety Evaluation Report

Senior Management Review Group

Safety and Operations Review Committee

Transport Plan Independent Review Committee

technical safety requirements

unreviewed safety question

unreviewed safety question determination

work breakdown structure 


\section{ENVIRONMENTAL RESTORATION AND WASTE MANAGEMENT DEPARTMENT INDEPENDENT SAFETY REVIEW COMMITTEE PROGRAM MANAGEMENT PLAN}

\section{INTRODUCTION}

U.S. Department of Energy (DOE) Orders 5480.5 and 5481.1B require DOE contractors to provide independent review of safety related matters, such as those contained in Safety Analysis Reports (DOE Order 5480.23), Technical Safety Requirements (DOE Order 5480.22), and Unreviewed Safety Questions (DOE Order 5480.21). The DOE Idaho Field Office (DOE-ID) has implemented these Orders through Field Office Orders ID 5480.5A and ID 5481.1B. The requirement to prepare Safety Analysis Reports for construction projects is specified under DOE Order 6430.1A, Section 0110-5.2. The EG\&G Idaho, Inc., Safety Manual interprets these DOE Orders, translating them into guidance for preparation and review of safety analysis documents, as well as guidance in conducting reviews of facilities and their operational activities. Within EG\&G Idaho, independent reviews are conducted at both the department and the group level.

This Program Management Plan (PMP) describes and governs the Independent Safety Review Committee (ISRC) established within the Environmental Restoration and Waste Management Department (ER\&WMD). The ISRC performs independent safety reviews for the ER\&WMD as required and specified by the governing documents mentioned above.

This PMP defines the ISRC organization, work plan, and scope of work. The PMP is organized consistent with the requirements of DOE Order 4700.1, Project Management System. For the purpose of readability, this document shall use the term "program" to include not only the chartered activities of the ISRC, but also the related activities conducted by the chairman and staff. This PMP is subordinate to the ER\&WMD Implementing Program Management Plan, EGG-WM-10220.

\subsection{Purpose}

The DOE has established requirements for multi-tiered, independent reviews of safety related documents and activities. It is recognized that multiple levels of independent review provide assurance that activities will be conducted in a risk-based manner. This multi-tiered review approach does not remove safety responsibility from the design or operations organizations, rather, it provides for the additional :technical expertise to evaluate the biological, toxicological, chemical, electrical, mechanical, radio : gical, and other safety factors which a given activity may involve.

DOE Order 5480.5 requires the heads of field organizations to conduct independent safety reviews prior to authorizing activities, operations, and modifications that involve an unreviewed safety question (Section 7.e.6.b). It further requires that contractors provide for independent safety review of all changes to components, equipment, procedures, and systems required for facility safety (Section 8.b). 
Section 9 of DOE Order 5480.5 defines the specific requirements of the contractor's internal safety review system. The purpose of the ISRC is to provide the independent safety review required by DOE Order 5480.5 in concert with other safety review functions within EG\&G Idaho, as defined in this document.

\subsection{Scope}

EG\&G Idaho, Inc., has established the Senior Management Review Group (SMRG) which provides company oversight of all independent safety review activities. The SMRG reports to the general manager of EG\&G Idaho, Inc. At the department level, four separate independent safety review groups have been established. These groups are:

- The Safety and Operations Review Committee (SORC), which operates under the Power Reactor Programs Department (PRPD), and reviews nuclear reactor-related projects

- The Independent Safety Review Committee (ISRC), which reviews waste management and environmental restoration activities

- The Combined Independent Safety Review Group (CISRG), which reviews Administration, Facilities and Maintenance, and Engineering Research and Applications (ER 4 U) Department activities

- The Transport Plan Independent Review Committee (TPIRC), which operates under the ER\& WIMD and reviews transportation plans and Safety Analysis Reports for Packaging and transport systems for all INEL contractors.

This PMP addresses only the Waste Management ISRC, which provides independent safety re...ws as requested for the ER\&WMD. The ISRC program encompasses relevant safety, health, and environmental compliance disciplines, as well as quality assurance. 


\section{MISSION, GOALS, AND OBJECTIVES}

\subsection{Mission}

The mission of the ISRC is to provide the required independent review of all safety-related project, facility, and environmental restoration documents and activities under the jurisdiction of the ER\&WMD. The ISRC formally provides independent opinion to the department manager on whether ER\&WMD safety documents and activities maintain a high degree of safety, health protection, quality assurance, and environmental compliance.

\subsection{Goals}

DOE has directed all contractors, including EG\&G Idaho, Inc., to put protection of workers, the public, and the environment ahead of production goals. The primary goal of the ISRC is to assist the ER\&WMD in fulfilling this direction. In order to meet the primary goal, the ISRC must:

- Comply with DOE Orders that require safety reviews independent of line management responsibility

- Review ER\&WMD safety documents and provide independent opinion on whether environment, safety, and health (ES\&H) matters are comprehensively addressed; that all identifiable risks are reduced to acceptably low levels; and that management authorization of the operation is documented

- Provide independent opinion to the ER\&WMD manager that readiness reviews and safety documents prepared for the programs and department have been prepared in accordance with EG\&G Idaho standards and are accurate in their form, content, and conclusions.

\subsection{Technical Baseline Objectives}

The primary objective of the ISRC is to review proposed and ongoing department safety documents in the breadth and depth necessary to provide an opinion on whether significant hazards have been identified, appropriate mitigating features provided, risks properly evaluated, and compliance achieved with applicable requirements as defined in the governing DOE Orders.

This PMP is written in accordance with DOE Order 5480.5 (Paragraphs 8.b, 8.m, and Section 9), 5481.1B (non-nuclear facilities), 5480.21, 5480.22, 5480.23 and related Field Office Orders.

Specific task-oriented objectives, which support the mission, goals, and primary objective, are detailed in the following subsections.

\subsubsection{Document Reviews}

An objective of the ISRC is to provide independent review of safety documentation to assure compliance with safety standards and requirements. Documents subject to ISRC review include: 
- Hazard Class Determination (HCD), prepared and used as a separate document only for non-nuclear facilities and activities not covered by DOE Order 5480.23 but still covered by DOE Order $5481.1 \mathrm{~B}$

- Safety Analysis Report (SAR), prepared in accordance with DOE Order 5480.23. These reports document the adequacy of the safety analysis for a nuclear facility to ensure that it can be constructed, operated, maintained, shut down, and decommissioned safely and in compliance with applicable laws and regulations. SARs may be prepared, reviewed, and approved in two stages: (1) a Preliminary Safety Analysis Report (PSAR) prepared in conjunction with the conceptual design, and (2) the Final Safety Analysis Report (FSAR), prepared in conjunction with detailed design and construction.

- Technical Safety Requirements (TSR), prepared in accordance with DOE Order 5480.22. The TSR defines the bounding conditions for safe operation of a facility. The TSR include the management and administrative controls required to ensure continued safe operation of the facility. The TSR is based on the facility SAR and is prepared, reviewed, and approved prior to operation.

- Restart Plans. The ISRC is ienuired to review restart plans following an SAR or TSR violation that results in operations curtailment.

- Unreviewed Safety Question Determination (USQD), prepared in accordance with DOE Order 5480.21. An Unreviewed Safety Question (USQ) may arise during the lifetime of a plant or facility due to changes and modifications being made in the normal mode of operations. USQDs may also be a result of discovered inadequacies of the currently accepted SAR.

- Other safety related documents or program reviews as requested by the ER\&WMD manager.

\subsubsection{Evaluation}

An objective of the ISRC is to provide independent evaluations of documents and procedures to determine ways to improve safety. Specific ISRC evaluations include the following:

- Annual evaluation of all Occurrence Reports (ORs) to determine trends and to make recommendations for safety improvement

- $\quad$ Serve as safety process observer during readiness reviews

- Evaluate the adequacy of group-level independent safety review functions

- Evaluate the safety analysis process for ER\&WMD activities and systems. Document the result in Safety Evaluation Reports (SERs). 


\subsubsection{Training}

An objective of the ISRC is to ensure that committee members are trained in their duties. To accomplish this, the ISRC staff facilitates training sessions as required to update committee members on ISRC review requirements as well as changes in safety requirements, standards, and codes. 


\section{Organization and Responsibilities}

The ISRC organization structure is shown in Figure 1 . The organization consists of ISRC staff members, the primary committee members, the alternate committee members, and the criticality subcommittee.

The ISRC reports in an advisory capacity to the ER\&WMD manager through the ISRC Chairman. The ISRC is responsible for the adequacy of the independent revi process and shall review upper tier safety documents to DOE Orders 5480.23 (SAR), 5480.22 (TSR), 5480.21 (USQ), and ID-5481.1B (Safety Analysis and Review System for Non-Nuclear Facilities).

The ISRC is responsible for the independent review of activities that directly affect or have the potential to affect safety, health, environmental compliance, and quality ass : rance. An independent review is defined as a critical and objective examination of an operation lalified individuals for the purpose of determining the adequacy of the safety analysis and safety controls. The review is considered independent if performed by a group of individuals, the majority of whom are not directly involved in the management or conduct of the activity being evaluated (EG\&G Idaho, Safety Manual, Section 2, Subsection 4).

\subsection{ISRC Staff}

The ISRC staff consists of the ISRC chairman, staff engineer(s), administrator(s), and alternate chairman. The ISRC staff provides management $a-t$ administrative support for the overall ISRC activity. The alternate chairman provides coverage in the event the chairman is not available or lacks independence.

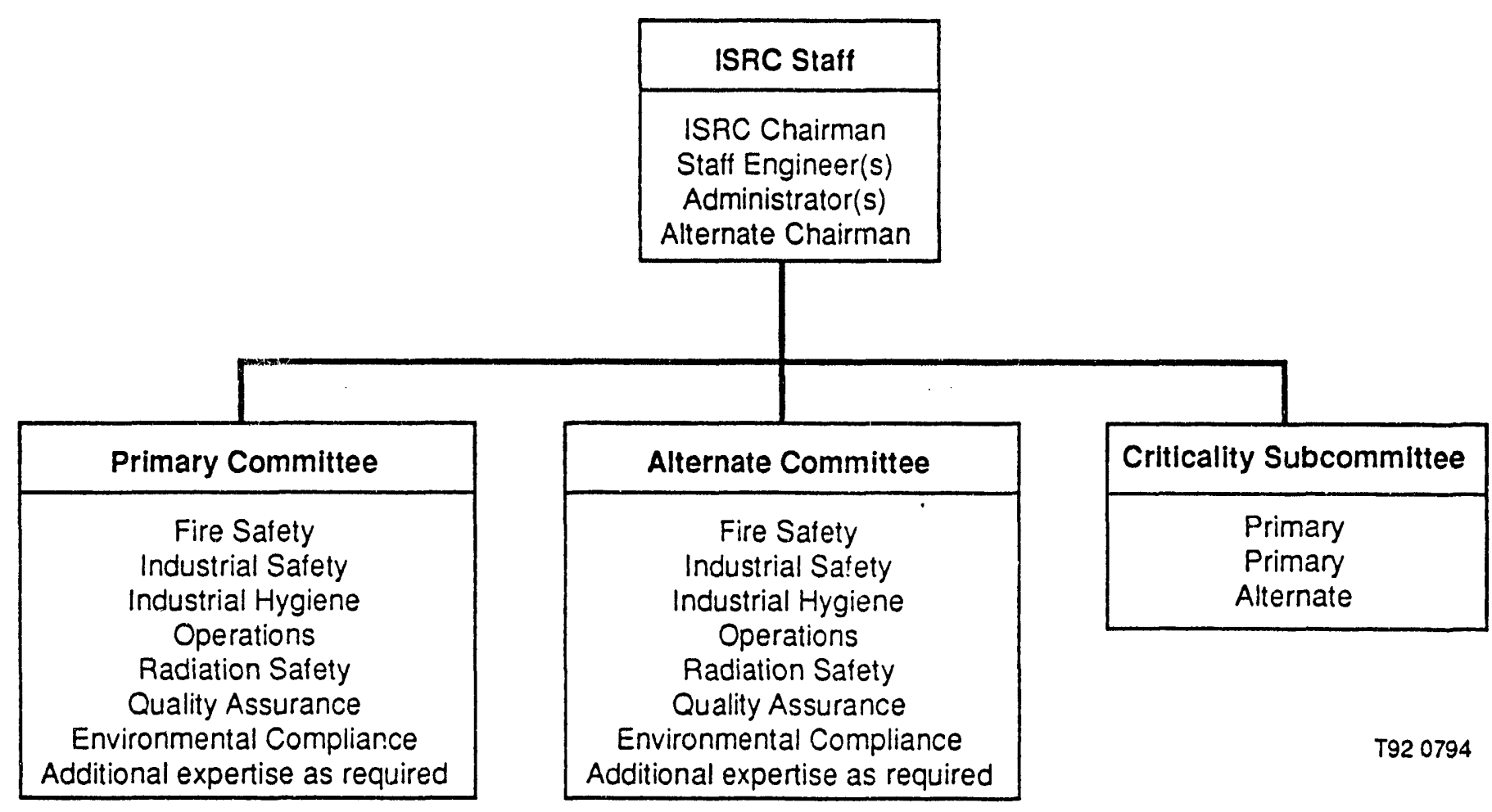

Figure 1. ISRC organization chart. 
NOTE: The "(s)" behind staff engineer and administrator indicate that these positions may be supple:-...... thy additional staff, as required.

The ISRC chairman is responsible for organizing and managing the activities and work scope of the ISRC in accordance with this PMP. The chairman delegates program management, prcgram control, and administration tasks to the staff engineer(s) and administrator(s), as appropriate. The ISRC staff shall assure all personnel performing reviews have been trained in their responsibilities, and that the training history is documented. The ISRC staff shall maintai- auditable documentation of all review activities.

\subsection{Committee Members}

The ISRC committee members have been structured into three subgroups: the primary committee, the alternate committee, and the criticality subcommittee. The committee members within these subgroups are principally chosen from a body of cognizant technical professionals within the ER\&WMD. Committee members shall be qualified personnel having sufficient education, experience, expertise, and training to allow for an understanding and thorough evaluation of the issues being reviewed.

To assure that reviewers are not required to evaluate their own work, each primary committee member has an alternate committee counterpart. Review tasks are assigned to committee members who have not contributed directly to the items being reviewed. An independent review is assured by making decisions as a committee.

The primary and alternate committees consist of at least seven members who are qualified professionals representing the following technical fields: industrial safety, industrial hygiene, operations, environmental compliance, radiation safety, and quality assurance. Other reviewers providing additional expertise may be selected, as required. Committee members are responsible for professional quality reviews in the area of their expertise, as specified in the EG\&G Idaho, Safety Manual, Section 2, Appendix I and the Company Procedures, Section 4.3. Members are selected by the ISRC chairman and appointed by the ER\&WMD manager. Members serve for a minimum of one year. To be selected as a primary or alternate committee member, the individual must by qualified in accordance with the EG\&G Idaho, Inc., Safety Manual, Section 1, Paragraph 3.6, Radiation Control Manual, Chapter 10, Paragraph 3.6, or Quality Manual Section 12 and Appendix VIII as applicable to the particular profession. Where specific qualification standards for a review discipline are not specified, reviewers shall be selected based on education and work experience. In order to perform independent reviews, an understanding of the authorization basis of the facility, and of specific requirements of the DOE Orders and policies, must be obtained.

A criticality subcommittee consisting of two members, a primary and an alternate, is included in the ISRC organization structure. A member of the criticality subcommittee shall participate in an ISRC review to verify calculations and assumptions whenever the review involves an actual or potential criticality issue. Members of the criticality subcommittee must be qualified according to EG\&G Idaho, Inc. Procedures Manual Volume II, Section 7.2, Paragraph 2.1.4. Through the criticality subcommittee, consideration is given to potential criticality hazards associated with fissionable material operations. 


\section{WORK PLAN}

The ISRC work plan is illustrated in the work breakdown structure (WBS), Section 5 (Figure 2). The ISRC work plan, discussed in this section, will describe each ISRC WBS element.

\subsection{Program Management}

As with any Program, there are a number of management activities necessary to conduct the Program in a well planned and controlled manner. The ISRC's program management activities are shown on the WBS (rigure 2) as level 1000 elements, which include:

1100 Development and maintenance of the ISRC governing documents. This includes the ISRC PMP, the ISRC Charter (issued as a ER\&WMD Directive), and ISRC detailed review procedures. Included in this activity is 'pdating the ISRC members with the latest revisions of the DOE Orders and governing documents.

1200 Staffing actions. The ISRC chairman shall nominate qualified personnel to serve as ISRC members. The nomination is approved by the ER\&WMD manager. Once members are nominated, appointed, and have agreed to serve, the ISRC staff assures that they receive training in their duties. The ISRC staff shall develop training courses to cover subjects listed in WBS element 4100.

1300 Program control functions. The ISRC staff shall develop and maintain appropriate program contiol documents and procedures. These include but are not limited to:

- Procedures for scheduling document reviews, evaluation activities, committee member training, and review meetings

- An auditable data base for filing information on review activities, tracking ISRC commitments, and tracking activity schedules

- A document control system for ISRC procedures and governing documents

- A program cost control system

- Main'enance of a filing system containing review plans, meeting minutes, evaluation reports, and other review documentation.

\subsubsection{Management Deliverables}

The end product of the level 1000 WBS activities performed by the ISRC staff is the necessary program organization and approved governing documentation to ensure that high quality services are produced and provided according to applicable DOE Orders and that all program activities are documented. 


\subsection{Document Reviews}

The ISRC document review activity is shown on the WBS (Figure 2) as level 2000 elements. It is the responsibility of the ER\&WMD manager to determine the need for an independent review of facility safery documents and to request the review by the ISRC. All nonstandard references must be provided to the ISRC chairman by the requesting manager.

The ISRC chairman shall assign review tasks to committee members, assuring that the majority of the participants are not directly involved in the management of the activity being evaluated or in the preparation of the document being reviewed. The ISRC chairman shall write a review plan detailing the requirements and schedule for the review and shall transmit the written plan with the review materials to the appropriate committee members. The scope of the review plan shall be commensurate with the document being reviewed and may be as simple as identification of the schedule and review team.

At the conclusion of the review process by each assigned committee member, the chairman shall convene a review meeting according to the written review plan. The meeting shall provide group discussion between reviewers on concerns and comments found in individual review activities. For committee actions, a quorum must exist, which consists of the chairman or the alternate, plus four members or their alternates.

\subsubsection{Documents Reviewed}

The level 2000 WBS elements define the documents to be reviewed by the ISRC, which include:

2100 Hazard Class Determination. The review shall confirm or challenge the reported hazard class of the activity according to current DOE Orders and EG\&G Idaho, Manuals. Existing HCDs shall be annually reviewed by a group-level line management independent review (LMIR) for appropriateness according to current [OOE Orders. If the LMIR determines that changes are required, the revised document will be returned to the ISRC for review.

2200 Safety Analysis Report. The ISRC shall review all new or updated SARs. Existing SARs shall be annually reviewed by a LMIR for appropriateness according to current DOE Orders. If the LMIR determines that changes are required, the revised document will be returned to the ISRC for review.

2300 Technical Safety Requirements. The ISRC shall review all new or updated TSR. Existing TSR shall be annually reviewed by a LMIR for appropriateness according to current DOE Orders. If the LMIR determines that changes are required, the revised document will be returned to the ISRC for review.

2400 Unreviewed Safety Question Determinations. The ISRC shall review all determinations concerning the possible existence of a USQ.

2500 Restart Plans. The ISRC shall review all restart plans following an SAR or TSR violation that has resulted in operations curtailment. 

safety-related issues.

Review other documents or activities as requested by the department manager.

\subsubsection{Document Review Process}

The primary focus on all reviews is safety and quality. All documents shall be reviewed for form, content, completeness, readability, and technical accuracy. Calculations may be verified or challenged. References may be reviewed to verify their intended application. If any document revision is submitted for review, the entire document may be open for review.

The ISRC representatives performing the review shall focus on their respective field of expertise according to the considerations given in the EG\&G Idaho, Safety Manual, Section 2, Appendix II and the Company Procedures Manual, Section 4.3. The review process shall determine if all significant ES\&H hazards have been identified; if the ES\&H hazards have been evaluated correctly, in terms of consequences and probability; if adequate measures have been taken or planned to eliminate or mitigate the hazards; if fissionable materials could be present in critical-mass quantities and configurations; if compliance of the design, construction, and operation of the activity is adequately demonstrated against applicable guides, codes, and standards; and if DOE design criteria have been properly evaluated. The review shall flag any items that raise concerns about compliance with DOE and DOE-ID Orders; Federal, State, and local regulations; and EG\&G Idaho, standards. The review shall conform to the requirements, standard, and guidance of the documents listec in Table 1.

\subsubsection{Document Review Deliverables}

The review iesults shall be compiled into an evaluation report producing an auditable trail of topics reviewed, issues raised, resolutions reached, actions taken, and final conclusions. The evaluation report shall recommend approval or disapproval of the reviewed document, with any recommendations or reasons for disapproval. The evaluation report and detailed meeting minutes comprise the end product of the review, called the review package. The completed review package shall be transmitted to the ER\&WMD manager. A copy of the review package shall be transmitted to the SMRG, the responsible program manager, the author, and members of the review committee, at a minimum. Each review package produced shall be retained by the ISRC for a minimum of 10 years, in accordance with DOE Order 1324.2A, attachment V-1:

\subsection{Safety Evaluations}

Safety evaluations of ER\&WMD programs shall be conducted as required by the ISRC. The ISRC chairman shall assign evaluation tasks to committee members or staff members, assuring that the participants are not directly involved in the management, design, or operation of the activity being evaluated. The ISRC chairman shall include the requirements and schedule of the evaluation when making evaluation assignments.

At the conclusion of the evaluation, the evaluator shall prepare a report which documents the findings and recommendations of the evaluation. The report shall be transmitted to the ISRC chairman. 
Table 1. Review standards and guidance documents.

\begin{tabular}{|c|c|c|}
\hline Document number & Document title & ISRC usage \\
\hline DOE Order 5480.5 & Safety of Nuclear Facilities & $\begin{array}{l}\text { Establishes the ISRC Basis \& } \\
\text { Requirements }\end{array}$ \\
\hline DOE-ID-5480.5A & Safety of Nuclear Facilities & $\begin{array}{l}\text { Establishes the ISRC Basis \& } \\
\text { Requirements }\end{array}$ \\
\hline DOE Order 5481.1B & Safety Analysis and Review System & $\begin{array}{l}\text { ISRC Reviews to this } \\
\text { Document }\end{array}$ \\
\hline DOE-ID-5481.1B & Safety Analysis and Review System & $\begin{array}{l}\text { ISRC Reviews to this } \\
\text { Document }\end{array}$ \\
\hline DOE Order 5480.21 & Unreviewed Safety Questions & $\begin{array}{l}\text { ISRC Reviews USQDs to this } \\
\text { Document }\end{array}$ \\
\hline DOE Order 5480.22 & Technical Safety Requirements & $\begin{array}{l}\text { ISRC Reviews TSR to this } \\
\text { Document }\end{array}$ \\
\hline DOE Order 5480.23 & Nuclear Safety Analysis Reports & $\begin{array}{l}\text { ISRC Reviews SARs to this } \\
\text { Document }\end{array}$ \\
\hline \multirow[t]{2}{*}{$\begin{array}{l}\text { DOE Order } 1324.2 \mathrm{~A} \\
\text { Attachment } \mathrm{V}-1\end{array}$} & Records Disposition & $\begin{array}{l}\text { ISRC Retains Records to this } \\
\text { Document }\end{array}$ \\
\hline & EG\&G Idaho, Inc., Safety Manual & $\begin{array}{l}\text { ISRC Reviews to this } \\
\text { Document }\end{array}$ \\
\hline
\end{tabular}

Level 3000 WBS elements define the evaluation activities performed by the ISRC.

3100 Occurrence Report Trends. The ISRC shall annually review ORs from facilities under the r cognizance, to assess significant trends, root causes, generic implications, and need for corrective action.

3200 Group Level Independent Safety Review Evaluations. The ISRC shall evaluate the adequacy of the group level review process performed by the ER\&WMD. The ISRC shall assure the group level review functions provide the necessary review of lower-tier documents and activities.

3300 Readiness Review Evaluations. An ISRC observer shall be present at all readiness reviews for major departmental activities.

3400 Safety Evaluation Report. The SER is an upper-level report evaluating the operations of a program or facility as a whole. The SER evaluates the following: assigned responsibilities, authorities, organization, and staffing of safety organizations and committees; safety training programs; radiation and hazard protection. plans and procedures; management procedures; effectiveness and comprehensiveness of audits and reviews; contamination control programs; procedures for reporting infractions, incidents, 
and safety violations; management and control of safety records; and other appropriate issues. The SER verifies the program and operation complies with all applicable DOE Orders, requirements, and directives. The SER is prepared by the ISRC. The SER is a new requirement by DOE Order 5480.23 .

\subsubsection{Safety Evaluation Deliverables}

The significant findings of safety evaluations shall be compiled into an evaluation report that provides an auditable trail of issues found, resolutions reached, actions taken. and final conclusions. The evaluation report shall identify items that need attention or correction. The evaluation report is prepared by the individual performing the evaluation, and comprises the end product of a safety evaluation. The evaluation report shall be given to the ISRC chairman, who will review the report and forward as it, as required to, the ER\&WMD manager and the SMRG. Each evaluation report shall be retained by the ISRC for a minimum of 10 years, in accordance with DOE Order 1324.2A, attachment V-1.

\subsection{Training and Process Improvement}

Level $4000 \mathrm{WBS}$ elements define the training and process improvement tasks performed by the ISRC.

4100 ISRC Member Training Courses. The ISRC staff shall prepare training courses for the purpose of keeping committee members trained in their duties and to keep them updated on review requirements and changes in safety standards, DOE siandards, and ISRC governing documents. Training sessions available through the ISRC staff cover three basic topics: (1) Tentative Hazard Classification, (2) Safety Analysis Reports and Technical Safety Requirements, and (3) Unreviewed Safety Questions. Each ISRC member is required to attend all of these sessions within three months of becoming an ISRC member. A yearly review and update of these sessions is required for each continuing member. This training does not duplicate the more intensive training for document authors on SAR, TSR, and USQDs provided by the ER\&WM Chemical Radiation and Technical Support Unit. Other training topics pertinent to the ISRC may be taught at the discretion of the ISRC chairman.

4200 The ISRC staff shall annually review the governing documents to ensure that they are current and that they accurately reflect the mission and purpose of the ISRC. The ISRC staff shall specifically review this PMP and lower-level ISRC documents to ensure that they remain in compliance with revisions and updates in DOE Orders and directives.

As with any work process, improvement ideas and recommendations shall be identified as a result of the day-to-day function of the ISRC. As process improvements are implemented, the ISRC governing documents shall be updated to reflect the changes in the work process and organizational interactions.

4300 Document Preparation Consultation. The ISRC shall serve as a focal point for interpretation of questions for the ER\&WMD on issues raised in safety analysis document

preparation. The ISRC shall serve as a technical safety resource to provide assistance to 
the ER\&WMD manager and the Company in preparing safety analysis documents as required by DOE Orders and directives.

\subsubsection{Training and Process Improvement Deliverables}

Deliverables for the level 4000 WBS elements include: a consistent, written training plan for all members of the ISRC, with documented records of committee member training history; process improvement records that document changes in ISRC governing documents as process improvements are approved and implemented; and a department-level resource of experienced safety professiona's to provide consultation in preparing safety dc suments for the department. 


\section{WORK BREAKDOWN STRUCTURE}

The ISRC's WBS is presented in Figure 2 


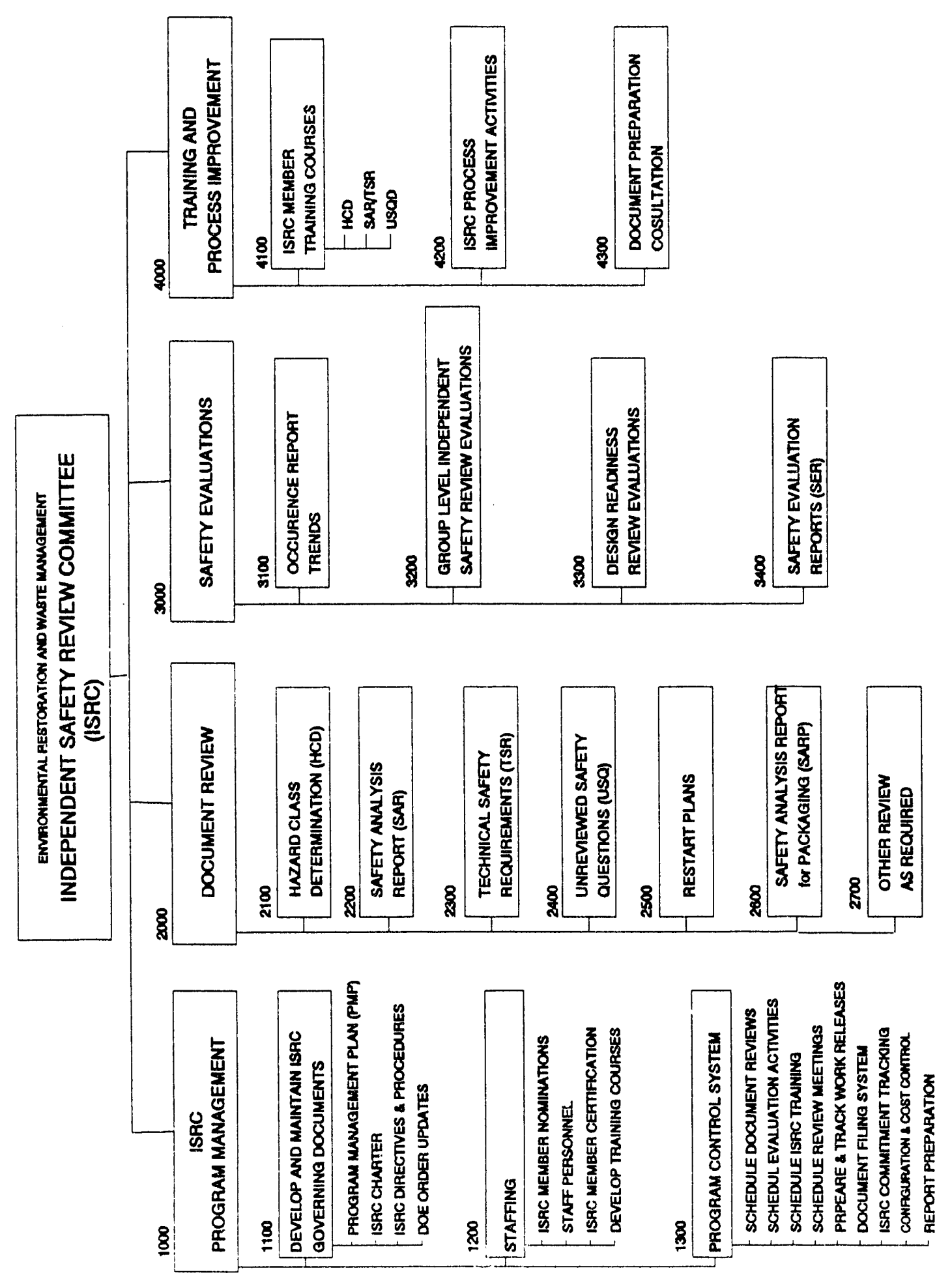

Figure 2. ISRC work breakdown structure. 


\section{PROGRAM SCHEDULE}

The overall ISRC program schedule shall be included in the current year ISRC woik package. The ISRC program schedule shall include all ISRC activities as defined in the work plan (see Section 4). Milestones for specified deliverables shall be established and met to meet customer requirements and programmatic deadlines. The ISRC staff shall optimize the utilization of the staff and committee members by blending anticipated document reviews with safety audits, inspections, evaluations, training, and consultation activities. 


\section{PERFORMANCE CRITERIA}

Applicable DOE Orders and EG\&G Idaho, manuals establish the overall performance criteria for the ISRC. This section will define specific ISRC performance requirements in the areas of technical performance, schedule performance, and cost performance.

\subsection{Technical Performance Criteria}

Technical performance requirements for the ISRC are:

- $\quad$ Records shall be maintained by the ISRC in sufficient detail to verify that all requirements set forth in this PMP are met

- ISRC members, as applicable, shall be qualified to the EG\&G Idaho, Safety Manual, Section 1, Subsection 3.6 and Quality Manual Section QP-2

- ISRC members shall be trained by the ISRC staff as defined in this PMP; records shall verify initial training and yearly training review and update

- The performance of the ISRC review process shall be documented in meeting minutes and in evaluation reports with sufficient detail to permit EG\&G Idaho, and DOE-ID to evaluate the effectiveness of ISRC reviews through audits

- The following evaluations shall be conducted by the ISRC annually:

- Occurrence Report evaluations and trending

- Evaluation of group-level independent reviews

The results shall be documented in an evaluation report in sufficient detail to permit EG\&G Idaho, Inc., and DOE-ID to audit the activity to determine its effectiveness

- At least one ISRC member shall attend readiness reviews for major departmental activities

- Implementing procedures shall be developed and maintained which define the ISRC processes and provide written instructions to ISRC personnel.

\subsection{Schedule Performance Criteria}

The ISRC shall complete ER\&WMD document reviews within six weeks of receiving a formal and correct request unless the other specific arrangements are made with the requestor. Evaluations shall be scheduled in the ISRC work package such that they are complete and documented within one year of each other. 
The schedule performance criteria is that all program activities shall be accomplished within $10 \%$ of the ISRC program schedule as approved in the current year work package. The ISRC chairman shall explain and document any variance greater than $10 \%$.

\subsection{Cost Performance Criteria}

The ISRC annual program budget, defined in Section 8.1, is detailed in the ISRC back-up documentation (BUD) number 12-E1, and detailed for the current year in the ISRC work package. The cost performance criteria for the annual program budget is that all program activities shall be accomplished within $10 \%$ of the approved work package baseline. The ISRC chairman shall explain and document any variance greater than $10 \%$ of the annual program budget. 


\section{COST AND STAFFING}

The ISRC funding process is broken down into two categories called the ISRC annual program budget and the individual document review budgets. In general, the WBS level 1000,3000, and 4000 activities are funded by the annual program budget. WBS level 2000 activities, except for the chairman's contributions, are funded through the document review budgets, provided directly from the requesting program manager.

\subsection{Annual Program Budget}

Reviews by ISRC members, alternates, or the criticality subcommittee covering several documents or activities at several facilities/programs are charged against the annual program budget. The annual program budget includes funding for ISRC activities which benefit multiple organizations, such as ISRC mianagement functions (WBS level 1000); document reviews and safety evaluations (WBS level 3000); and training, process improvement, and consultation activities (WBS level 4000). The ISRC staff personnel charge totally to the annual program budget. Also included in this budget are related expenses such as library materials, personnel development, office supplies, and other personnel required to support the ISRC who are not specifically listed in the ISRC organizational structure.

The annual program budget is detailed in the ISRC BUD 12-E1. Since the ISRC activities are ongoing and no ending date is forecast, BUD 12-E1 shall be updated annually to reflect the current year budget, the next year estimated budget, the third year planning budget, and at least three additional outyear planning budgets (current year plus a five-year plan). BUD 1.2-E1 shall include a complete summary of the ISRC orgarization structure in terms of funding levels planned for all ISRC members, staff members, and any additional support personnel.

\subsection{Document Review Budget}

Reviews of specific documents by ISRC members, alternates, or the criticality subcommittee are charged to the requesting department. These requests are made formally by the department or program manager and include a charge number for conducting the review. These budgets are called document review budgets. Document review budgets support only the tasks performed by members of the primary committee, the alternate committee, or the criticality subcommittee. The ISRC staff members are always supported through the annual program budget (BUD 12-E1).

\subsection{Work Package}

The ISRC Work Package is prepared annually and defines the annual program budget for the current year as contained in the BUD 12-E1. The work package ties the current year budget into the overall schedule logic diagrams. The ISRC work package provides the approved baseline budget and schedule for the current year and becomes the basis for all earned value reports provided to DOE-ID. 


\section{PROGRAM FUNCTIONAL SUPPORT REQUIREMENTS}

This section describes the relationships among the organizations which are part of the EG\&G Idaho, Inc., Independent Review and Appraisal System. Figure 3 shows the structure of this company system. The subsections below discuss the operating interrelationships and areas of responsibility of the organizations which have a significant interaction with the ISRC.

\subsection{Department of Energy, Idaho Field Office}

The DOE-ID responsibility in relation to the independent review and appraisal system includes:

- Assuring that the basic requirements of DOE Order 5480.5 are implemented for all facilities under DOE-ID programmatic jurisdiction [DOE-ID-5480.5A 4.c(6)(a)].

- Assuring that the contractor prepares and reviews facility SAR and TSR documents and conducts safety evaluations and changes consistent with DOE Orders. All SAR and TSR documents and any revisions, changes, or addenda shall be approved by DOE-ID prior to operation. All safety issues identified by the EG\&G Idaho, independent review and appraisal system shall have been resolved prior to submittal for DOE-ID approval (DOE-ID-5480.5A 4.c(6)(d); DOE-ID-5480.5A 4.c(6)(e); DOE-5481.1B 2.a(2); DOE 5480.23 7.b(1); DOE 5480.23 7.c(2); DOE 5480.22 8.a(1); EG\&G Idaho, Safety Manual Section 2, Subsection 3.3.4.f).

- Assuring that independent safety reviews are performed by the contractor and that continued operation is acceptable for environmental protection, safety, and health protection; and assuring that the contractor documents independent safety reviews according to DOE Orders (DOE 5480.5 7.e(6)(b)).

- Assuring prompt reporting by the contractor of noncompliance with DOE Safety Orders (DOE-ID-5480.5A 4.c(6)(c).3).

- Assuring that periodic audits are performed, that the hazard classification is appropriate and the facility is in compliance with SARs and TSRs; and assuring that all commitments made in the approved SAR are carried out by the contractors for the nuclear facilities and nuclear operations (DOE-ID-5481.1B 6.c(2); DOE 5480.23 7.b(3)).

- Providing guidance and assistance to field organizations in the performance of safety reviews, appraisals, and the preparation of SAR and TSR documents [DOE 5490.23 7.b(5); DOE 5480.22 8.a(7)].

- Actively monitoring the USQ identification, review, and decision-making process of contractors under their cognizance to determine whether an incident, analysis, or proposed change/modification to systems components, processes, operations, tests, or experiments involves a USQ; [DOE 5480.21 9.e(3)]. 


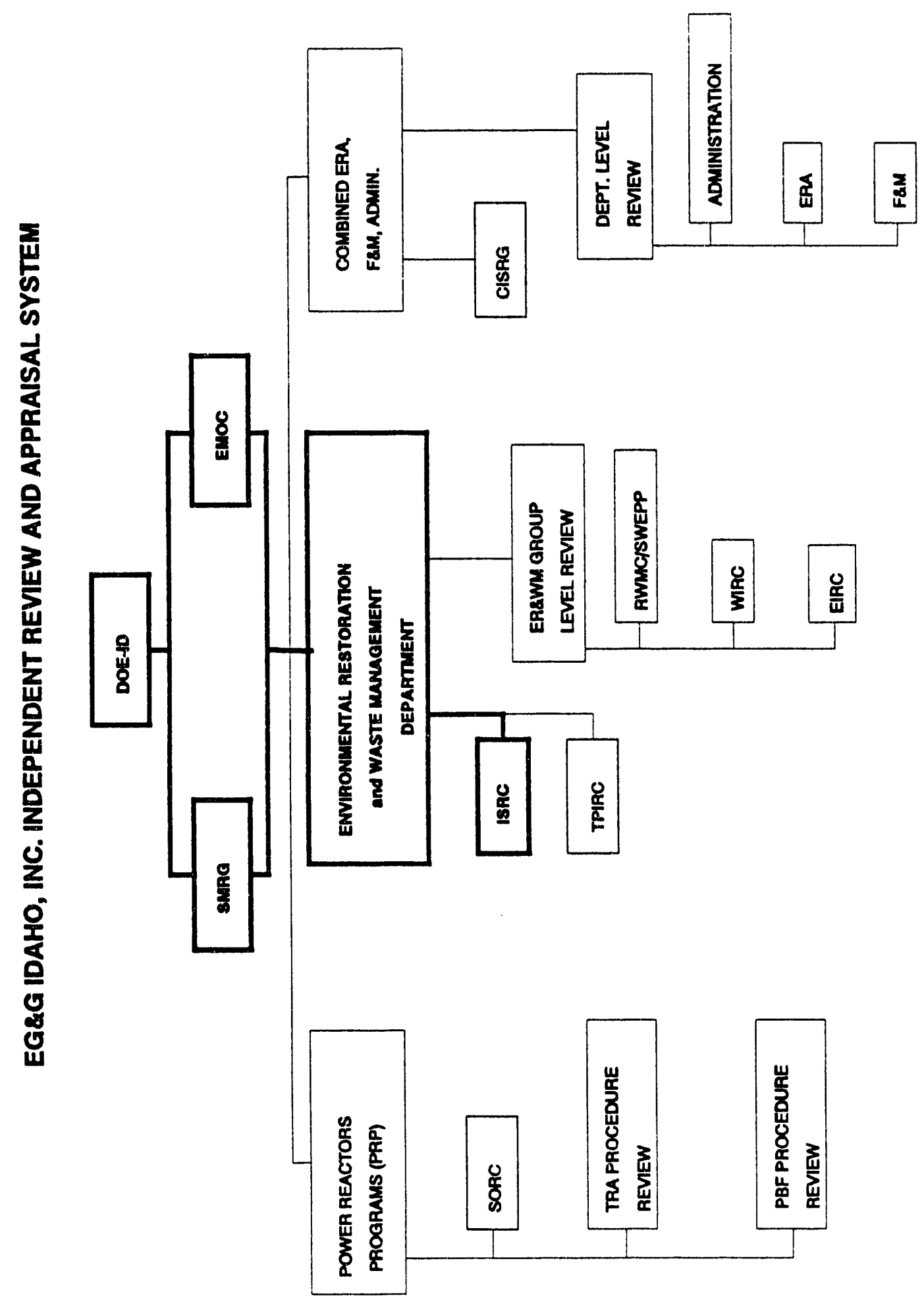

Figure 3. EG\&G Idaho, Inc., independent review and appraisal system. 
- Ensuring that program budgets provide adequate funds for health and safety requirements during all phases of facility life [DOE 5480.23 7.b.(13)].

\subsection{EG\&G Idaho, Inc.}

EG\&G Idaho, shall formally implement the policy and procedures contained in DOE Orders, Company procedures, and the Company Safety Manual which apply to the independent review and appiaisal system. EG\&G Idaho, shall take all reasonable precaltions in the performance of work under their contract to protect the health and safety of employees and of members of the public, and shall comply with all applicable safety and health regulations and requirements of DOE.

\subsubsection{The Senior Management Review Group}

The SMRG is responsible for providing EG\&G Idaho, policy guidance, nuclear safety overview assessments, and key decisions on nuclear safety requirements and compliance. The SMRG was formerly called the Nuclear Safety Review Group (NSRG). The name has changed to reflect increased responsibilities of reviewing environment, safety, and quality (ES\&Q) issues, as well as nuclear safety issues.

The SMRG provides senior management oversight in the area of nuclear safety and ES\&Q issues. The SMRG is a standing committee composed of senior managers and external consultants, chaired by the General Manager of EG\&G Idaho, Inc. The SMRG is supported by a technically qualified staff who are independent of the activities evaluated by the SMRG. The SMRG reviews ongoing nuclear operations as needed to assess the effectiveness of the line management independent review committees and strength of management controls to assure compliance with DOE Orders and directives. The SMRG reviews SAR and TSR documents prior to submittal to DOE-ID for approval. The SMRG reviews reports and meeting minutes of the department-level independent review committees.

The SMRG consists of the following members:

- EG\&G Idaho, general manager (chairman)

- $\quad$ ERAD manager (deputy chairman)

- $\quad$ ER\&WMD manager

- $\quad E S \& Q$ department manager

- $\quad$ ES\&Q staff (administrator)

- Facilities and Maintenance (F\&M) department manager

- $\quad$ PRPD manager

- External consultants as needed. 


\subsubsection{The Environmental/OSHA Management Oversight Committee}

The Environmental/OSHA Management Oversight Committee (EMOC) focuses senior management attention on environmental and non-nuclear safety issues, particularly in directing and monitoring progress to achieve total compliance. The EMOC consists of:

- EG\&G Idaho deputy general manager (chairman)

- ES\&Q department manager (executive secretary)

- $\quad$ ER\&WMD manager

- $\quad$ PRPD manager

- F\&M manager

- General counsel.

\subsubsection{The Transport Plan Independent Review Committee}

The TPIRC reviews transport plans and safety analysis reports for packaging and transport systems to determine if all safety issues have been identified, mitigating features provided, and compliance achieved. The TPIRC supports transport activities for all INEL contractors.

\subsubsection{EG\&G Idaho, Department Managers}

The organizational structure and charter of EG\&G Idaho, assigns department managers the responsibility for both production and safety. Department managers shall ensure the establishment of department-level and group-level independent review committees. These reviews shall serve as the basis for a decision by the responsible department manager to initiate operations. The review committees shall function as an advisory capacity to the department managers, providing review findings, conclusions, and recommendations to aid in the decision process.

The department manager is responsible to maintain a permanent file for all pertinent analyses, reviews, and authorizations relative to any DOE operation. The documents shall be traceable and auditable according to DOE Orders and directives.

The department manager is responsible to initiate safety document reviews with the independent review committees. Prior to submitting documents for review, the department manager shall assure all technical details and administrative requirements are addressed, and that the technical content and quality of documents are sufficient to allow meaningful independent reviews.

Department managers are responsible for resolution of all findings and concerns described in the evaluation report of the review committees. 


\subsubsection{Safety and Operations Review Committee}

The SORC operates under the PRPD, and provides department-level independent reviews for nuclear reactor-related projects.

\subsubsection{Combined Independent Safety Review Group}

The CISRG conducts department-level independent safety reviews for Administration, F\&M, and ERAD activities.

\subsubsection{Independent Safety Review Committee}

The ER\&WMD ISRC reviews environmental restoration and waste management activities as described in this PMP. 


\section{PROJECT MANAGEMENT, MEASUREMENT, AND PLANNING AND CONTROL SYSTEMS}

The system of management employed by the ISRC conforms in broad measure to the requirements of DOE Order 4700.1, Project Management System. This PMP provides the program management guide to be used for all ISRC activities, which includes:

- A formal schedule and cost baseline with the ability to accommodate document review requests on an ongoing basis. The schedule baseline is defined in Section 6 and the ISRC work package. The cost baseline is defined in Section 8, BUD 12-E1, and the ISRC work package.

- Specification of a $10 \%$ maximum variance in schedule and cost.

- Regular monthly reporting to DOE-ID (see Section 11).

The primary objective of the ISRC management control system (MCS) is to ensure that planning and execution of the program is technically sound, timely, cost-effective, and in conformance with DOE Orders, EG\&G Idaho, procedures, and this PMP.

Program level planning includes the development, issuance, and maintenance of this PMP, as well as subordinate department-level documents that provide the detailed charter, work process procedures, and responsibility checklists of the ISRC. These subordinate documents shall define in detail how the ISRC management implements the details of this PMP.

\subsection{Program Planning and Budgeting}

Planning is done in two stages: the ISRC BUD, which defines the current year budget plus a five-year budget plan; and the ISRC work package, which amplifies the current year budget contained in the BUD and ties it to the program schedule.

The annual detailed planning cycle is initiated by the ISRC chairman. Sufficient planning time shall be allowed to allow completion and approval of the annual BUD with the five-year plan, as well as the annual ISRC work package, by the beginning of each fiscal year.

The use of the WBS during the annual planning process is essential. The WBS ensures that all work is identified and included in the schedule and cost baseline development process. The WBS numbering system, detailed in Section 5, provides the integrating mechanism for baseline development and management.

\subsection{Performance Measurement and Control}

Progress measurement is accomplished using an earned value-based approach through measurement of progress against the current year work package. Again, a variance greater than $10 \%$ requires a variance statement preparation and corrective action identification. 


\section{INFORMATION AND REPORTING}

Formal and informal communications between the ISRC and DOE-ID are essential to ensure progress in the defined activities of the ISRC. Formal communications to DOE shall consist of the EG\&G Waste Management Monthly Report. This report uses earned value based tables and charts along with their associated discussions to present the status of technical baseline, cost, schedule, and variance information. The information in this report originates from the ISRC staff. This report is forwarded to DOE-ID during the first half of each month and covers the activities of the previous month.

Informal communications, in the form of program status, day-to-day issues, solutions to problems, travel reports, accomplishment reports, and similar deliverables, shall be documented and maintained in appropriate correspondence files. All agreements, commitments, orders, or reports shall be documented. Table 2 presents a summary of formal and informal ISRC deliverables.

Table 2. Summary of deliverables.

\begin{tabular}{|c|c|c|c|c|}
\hline Deliverable & $\begin{array}{c}\text { To } \\
\text { ISRC } \\
\text { Chairman }\end{array}$ & $\begin{array}{c}\text { To } \\
\text { ER\&WMD } \\
\text { Manager }\end{array}$ & $\begin{array}{c}\text { To } \\
\text { SMRG }\end{array}$ & $\begin{array}{l}\text { To } \\
\text { DOE-ID }\end{array}$ \\
\hline $\begin{array}{l}\text { Organized Independent Review Group for } \\
\text { ER\&WMD, (Section 4.1.1) }\end{array}$ & - & $\mathrm{X}$ & - & - \\
\hline $\begin{array}{l}\text { PMP and Subordinate Governing } \\
\text { Documents (Section 4.1.1) }\end{array}$ & - & $\mathrm{X}$ & - & - \\
\hline $\begin{array}{l}\text { Document Review Evaluation Report } \\
\text { (Section 4.2.3) }\end{array}$ & - & $\mathrm{X}$ & $X$ & \\
\hline Report of Safety Evaluations (Section 4.3.1) & $X$ & $\mathrm{X}$ & $\mathrm{X}$ & $\mathrm{X}$ \\
\hline ISRC Training Program (Section 4.4.1) & $\mathrm{X}$ & $\mathrm{X}$ & - & - \\
\hline $\begin{array}{l}\text { Safety Document Consultation (Section } \\
4.4 .1 \text { ) }\end{array}$ & - & $\mathrm{X}$ & - & - \\
\hline $\begin{array}{l}\text { Annual Budget and Five Year Plan, BUD } \\
\text { 12-E1 (Section 8.1) }\end{array}$ & - & $\mathrm{X}$ & - & $\mathrm{X}$ \\
\hline $\begin{array}{l}\text { Annual ISRC Work Package with Current } \\
\text { Year Budget and Schedule (Section } 8.3 \text { ) }\end{array}$ & - & $\mathrm{X}$ & - & $\mathrm{X}$ \\
\hline $\begin{array}{l}\text { EG\&G Waste Management Monthly Report } \\
\text { (Section 11) }\end{array}$ & - & $x$ & - & $\mathrm{X}$ \\
\hline Informal Communications (Section 11) & $\mathrm{X}$ & $\mathrm{X}$ & - & $X$ \\
\hline
\end{tabular}




\section{SYSTEM ENGINEERING MANAGEMENT}

The system engineering management process is normally implemented for major system acquisitions and major project activities, as set forth in DOE Orders 4700.1 and 2250.1C. The ISRC is neither. The system engineering management concepts of planning, design concepts, requirement definition, controls, and analysis have been adequately addressed in previous sections of this PMP. 


\section{CONFIGURATION MANAGEMENT}

Since the ISRC does not control facilities, equipment, devices, hazardous materials. engineering designs, software, and so forth, a configuration management plan is not required per EG\&G Idaho, Inc., Company Procedure 20.23. However, the ISRC chairman is responsible for configuration management of governing documents which include the PMP, as well as subordinate department-level documents which provide the detailed charter, work process procedures, and responsibility checklists of the ISRC. Configuration management of these documents is accomplished by issuing them as controlled documents using the current ER\&WMD document control system. 


\section{CHANGE CONTROL}

The procedure for controlling changes to the approved ISRC budget and schedule found in the ISRC work package is detailed in the EG\&G Idaho, Company Procedures Manual Section 20.24. This procedure shall be followed using the appropriate classification and Change Control Board level $(\mathrm{CCB})$ when making changes in the ISRC work package. 


\section{MANAGEMENT RESERVE}

Management reserve funds are not held by the ISRC management. 


\section{QUALITY ASSURANCE}

The EG\&G Idaho Quality Manual (QM) establishes quality assurance (QA) requirements for the Company. The provisions of this manual apply to the work performed by all EG\&G Idaho departmental elements and management. The purpose of this section is to specify which QA requirements of the QM apply to the ISRC and how each applicable requirement is met.

Table 3 lists the QM requirements, indicates which apply to the ISRC, and references the PMP section which describes how the requirement is met. This section forms the ISRC Quality Assurance Plan, which covers QA within the ISRC activities, rather than how the ISRC assures quality within the organizations for which it performs independent reviews.

Table 3. The ISRC Quality Assurance Plan.

\begin{tabular}{|c|c|c|c|}
\hline $\begin{array}{c}\text { EG\&G Idaho Inc., } \\
\text { Quality Manual } \\
\text { Requirement }\end{array}$ & $\begin{array}{l}\text { EG\&G Idaho } \\
\text { Inc., QM } \\
\text { Source }\end{array}$ & $\begin{array}{l}\text { Applies } \\
\text { to ISRC? }\end{array}$ & $\begin{array}{l}\text { Implemented } \\
\text { by ISRC PMP }\end{array}$ \\
\hline Organization & QP-1 & Yes & ISRC PMP Section 9 \\
\hline Quality Program & QP-2 & Yes & $\begin{array}{r}\text { ISRC PMP Section } 4.2 .2 \\
\text { Section } 4.4\end{array}$ \\
\hline Document Control & QP-6 & Yes & $\begin{array}{r}\text { ISRC PMP Section } 4.2 .3 \\
\text { Section } 4.4 \\
\text { Section } 13\end{array}$ \\
\hline Corrective Action & QP-16 & Yes & $\begin{array}{r}\text { ISRC PMP Section } 4.4 \\
\text { Section } 9 \\
\text { Section } 11\end{array}$ \\
\hline Quality Records & QP-17 & Yes & $\begin{array}{r}\text { ISRC PMP Section } 4 \\
\text { Section } 13\end{array}$ \\
\hline All other QP elements & $\begin{array}{l}\text { QP-3, 4, 5, } 7 \\
8,9,10,11 \\
12,13,14,15, \\
18,19,20, \\
\& 21\end{array}$ & No & $\mathrm{N} / \mathrm{A}$ \\
\hline
\end{tabular}




\section{RESPONSIBILITY MATRIX}

The ISRC operates under a single work package under the ER\&WMD. This is the lowest level of cost account management in which all ISRC. WBS elements are the responsibility of the ISRC chairman. No further responsibility assignment matrix is required. 

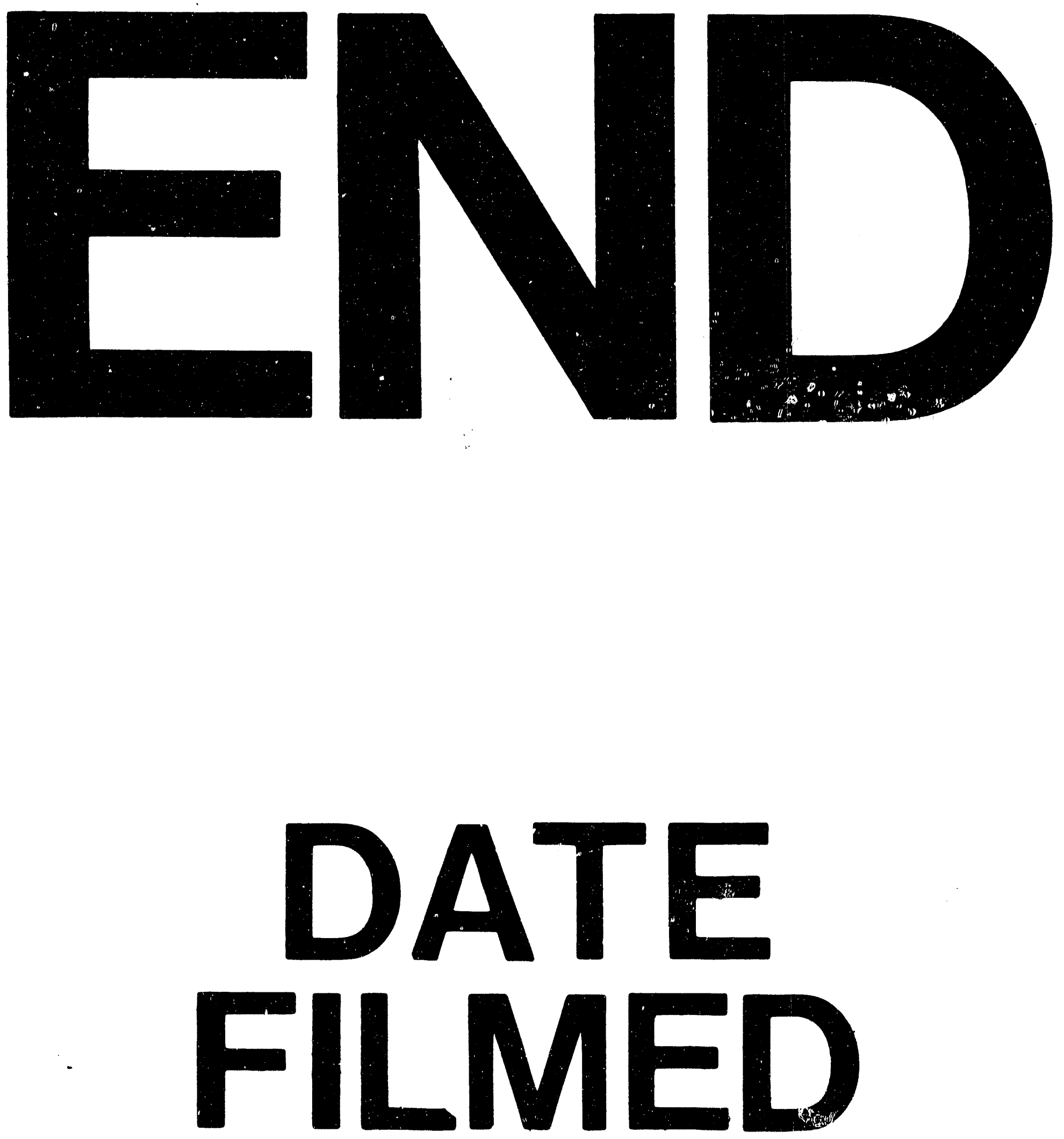

\}

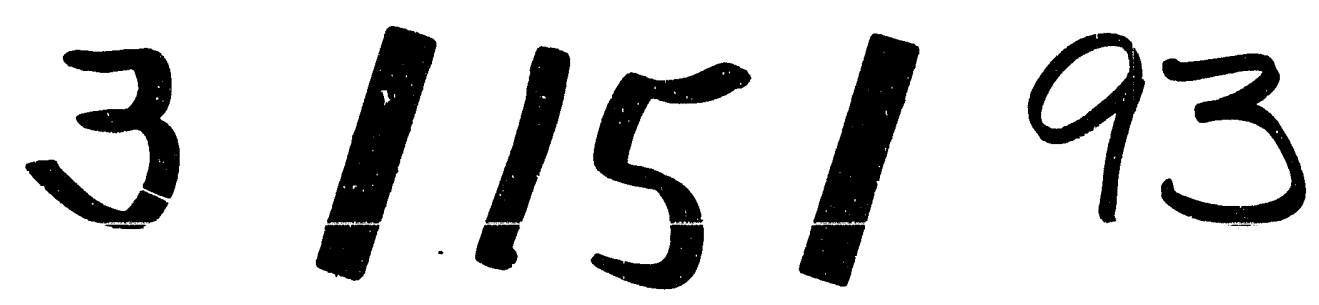


